NISTIR 8141

\title{
NIST/NIH Vitamin D Metabolites Quality Assurance Program Report of Participant Results: Summer 2014 Comparability Study (Exercise 9)
}

Mary Bedner Susan S.-C. Tai

This publication is available free of charge from: http://dx.doi.org/10.6028/NIST.IR.8141

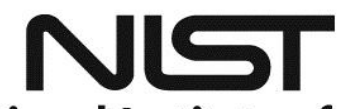

National Institute of Standards and Technology U.S. Department of Commerce 


\title{
NIST/NIH Vitamin D Metabolites Quality Assurance Program Report of Participant Results: Summer 2014 Comparability Study (Exercise 9)
}

\author{
Mary Bedner \\ Susan S.-C. Tai \\ Chemical Sciences Division \\ Material Measurement Laboratory
}

This publication is available free of charge from:

http://dx.doi.org/10.6028/NIST.IR.8141

September 2016

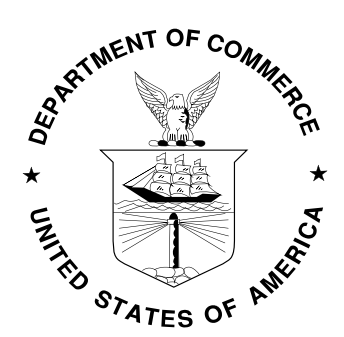

U.S. Department of Commerce

Penny Pritzker, Secretary

National Institute of Standards and Technology Willie E. May, Under Secretary of Commerce for Standards and Technology and Director 


\begin{abstract}
The National Institute of Standards and Technology (NIST) has established a Vitamin D Metabolites Quality Assurance Program (VitDQAP) in collaboration with the National Institutes of Health (NIH) Office of Dietary Supplements. Participants in the ninth exercise of this program, the Summer 2014 Comparability Study, were asked to use the methodology of their choice to measure concentrations of 25-hydroxyvitamin D in pooled human serum control and study materials distributed by NIST. The study materials consisted of Standard Reference Material (SRM) 2973 Vitamin D Metabolites in Frozen Human Serum (High Level) and VitDQAP-I (a material designed for the VitDQAP). SRM 968d Fat-Soluble Vitamins, Carotenoids, and Cholesterol in Human Serum Level 1 was provided as a control material. Participants provided their data to NIST, where it was compiled and evaluated for trueness relative to the NIST value and concordance within the participant community. A report of results was provided to all participants of the study, and laboratories were identified by code numbers known only to them. The results from this ninth study are reported along with a summary of the analytical methods used.
\end{abstract}




\section{OVERVIEW OF THE SUMMER 2014 COMPARABILITY STUDY}

For the Summer 2014 comparability study of the collaborative National Institute of Standards and Technology and National Institutes of Health (NIST/NIH) Vitamin D Metabolites Quality Assurance Program (VitDQAP), human serum control and study materials were distributed to participants for evaluation. Standard Reference Material (SRM) 968d Fat-Soluble Vitamins, Carotenoids, and Cholesterol in Human Serum Level 1 (SRM 968d L1) was provided as a control material for assay validation. For SRM 968d L1 (Control), the participants were provided the NIST target values within the data reporting sheet so that they could qualify their methods prior to analyzing the study samples. The study materials consisted of two vials, each containing a sample of pooled human serum. In this study, Vial A was VitDQAP-I, and Vial B was SRM 2973 Vitamin D Metabolites in Frozen Human Serum (High Level), both of which contain endogenous levels of the vitamin D metabolites. Participants were asked to determine 25-hydroxyvitamin D in each of the human serum control and study samples. Individual concentration values for 25hydroxyvitamin $\mathrm{D}_{3}\left(25(\mathrm{OH}) \mathrm{D}_{3}\right)$, 25-hydroxyvitamin $\mathrm{D}_{2}\left(25(\mathrm{OH}) \mathrm{D}_{2}\right)$, and 3-epi-25-hydroxyvitamin $\mathrm{D}_{3}\left(3\right.$-epi- $25(\mathrm{OH}) \mathrm{D}_{3}$ ) were requested along with a total concentration of 25-hydroxyvitamin $\mathrm{D}$ $\left(25(\mathrm{OH}) \mathrm{D}_{\text {Total }}=25(\mathrm{OH}) \mathrm{D}_{2}+25(\mathrm{OH}) \mathrm{D}_{3}\right)$.

There were a total of 53 participants and 63 datasets (nine participants provided data from two or more methods) in the Summer 2014 comparability study. Twenty-three of the datasets originated from immunoassay (IA) techniques, including 15 from chemiluminescence immunoassay (CLIA), two from enzyme immunoassay (EIA), five from radioimmunoassay (RIA), and one from chemiluminescent enzyme immunoassay (CLEIA). Appendix A-1 summarizes the IA methods used by the participants. Forty of the datasets originated from liquid chromatographic (LC) methods; of those, 35 were from $\mathrm{LC}$ with tandem mass spectrometric detection (LC-MS ${ }^{\mathrm{n}}$ ), and five were from LC with ultraviolet absorbance detection (LC-UV). A summary of the LC methods used by the participants may be found in Appendices A-2 and A-3.

The raw data received from all participants are summarized in Appendix B. The IA methods do not distinguish between $25(\mathrm{OH}) \mathrm{D}_{3}$ and $25(\mathrm{OH}) \mathrm{D}_{2}$, and IA participants reported single values for $25(\mathrm{OH}) \mathrm{D}_{\text {Total }}$ in the control and study materials. The LC methods measure the vitamin D metabolites separately, and the majority of the LC participants reported values for $25(\mathrm{OH}) \mathrm{D}_{3}$ in addition to $25(\mathrm{OH}) \mathrm{D}_{\text {Total }}$. The $25(\mathrm{OH}) \mathrm{D}_{2}$ concentration was below the detection limit for most reported methods in the control and study materials. Ten LC participants reported results for 3-epi$25(\mathrm{OH}) \mathrm{D}_{3}$.

Appendix B also provides the summarized NIST results for each of the serum materials. A detailed description of the NIST methods is provided in the next section of this report. 


\section{SUMMARY OF THE NIST METHOD USED TO EVALUATE THE CONTROL AND STUDY MATERIALS}

NIST used isotope dilution LC-MS/MS (ID-LC-MS/MS) [1] to determine the vitamin D metabolites $\left(25(\mathrm{OH}) \mathrm{D}_{3}, 25(\mathrm{OH}) \mathrm{D}_{2}\right.$, and 3-epi-25(OH) $\left.\mathrm{D}_{3}\right)$ in the control and study materials evaluated in this comparability study. The ID-LC-MS/MS approach is a reference measurement procedure (RMP) for $25(\mathrm{OH}) \mathrm{D}_{3}$ and $25(\mathrm{OH}) \mathrm{D}_{2}$ that is recognized by the Joint Committee for Traceability in Laboratory Medicine (JCTLM).

The NIST values for $25(\mathrm{OH}) \mathrm{D}_{3}, 25(\mathrm{OH}) \mathrm{D}_{2}$, and 3-epi-25(OH) $\mathrm{D}_{3}$ in VitDQAP-I (Vial A) are reported with expanded uncertainties $(U)$ that approximate a $95 \%$ confidence interval. $U$ incorporates components for measurement variability and measurement uncertainty associated with the density of the materials and the purity of the reference standards as well as a $1 \%$ type B uncertainty for unknown systematic errors, which is consistent with the practice used at NIST for clinical measurements [1]. For SRM 968d L1 (Control), the NIST values for $25(\mathrm{OH}) \mathrm{D}_{3}$ and 3-epi$25(\mathrm{OH}) \mathrm{D}_{3}$ are reported as described for VitDQAP-I (Vial A), but the value for $25(\mathrm{OH}) \mathrm{D}_{2}$ was well below the limit of quantitation and was estimated to be $0.1 \mathrm{ng} / \mathrm{mL}$ based on one measurement.

The values for $25(\mathrm{OH}) \mathrm{D}_{\text {Total }}$ in VitDQAP-I (Vial A) and SRM 968d L1 (Control) are the sum of the individual values for $25(\mathrm{OH}) \mathrm{D}_{3}$ and $25(\mathrm{OH}) \mathrm{D}_{2}$, and the expanded uncertainty $(U)$ incorporates measurement uncertainties for the two analytes.

For SRM 2973 (Vial B), the reported NIST value for $25(\mathrm{OH}) \mathrm{D}_{3}$ is a certified value. A NIST certified value is a value for which NIST has the highest confidence in its accuracy in that all known or suspected sources of bias have been investigated or taken into account [2]. The NIST values for $25(\mathrm{OH}) \mathrm{D}_{2}$, 3-epi-25(OH) $\mathrm{D}_{3}$, and $25(\mathrm{OH}) \mathrm{D}_{\text {Total }}$ in SRM 2973 (Vial B) are reference values. A NIST reference value is a best estimate of the true value provided by NIST where all known or suspected sources of bias have not been fully investigated by NIST [2]. More detailed information about the characterization of SRM 2973 and the components of the expanded uncertainty may be found in the Certificate of Analysis, located on the NIST website [3].

\footnotetext{
${ }^{1}$ Tai, S. S.-C.; Bedner, M.; Phinney, K.W.; Anal. Chem. 2010 82, 1942-1948.

${ }^{2}$ May, W.; Parris, R.; Beck II, C.; Fassett, J.; Greenberg, R.; Guenther, F.; Kramer, G.; Wise, S.; Gills, T.; Colbert, J.; Gettings, R.; MacDonald, B.; NIST Special Publication 260-136 2000; http://www.nist.gov/srm/publications.cfm

${ }^{3}$ http://www.nist.gov/srm/index.cfm
} 


\section{SUMMER 2014 COMPARABILITY STUDY RESULTS AND DISCUSSION}

\section{Results for 25(OH)DTotal}

A summary of the individual participant data for total 25 -hydroxyvitamin $\mathrm{D}\left(25(\mathrm{OH}) \mathrm{D}_{\text {Total }}\right)$ in VitDQAP-I (Vial A), SRM 2973 (Vial B), and SRM 968d L1 (Control) is provided in Table 1.

The community results are summarized at the bottom of Table 1 for all reported methods, the IA methods only, the LC methods only, and the LC-MS methods only. The community results include the total number of quantitative values reported $(\mathrm{N})$, the median value for each analyte, the MADe (the median absolute deviation estimate, a robust estimate of the standard deviation), and the percent coefficient of variation $(\mathrm{CV} \%)$.

Table 1 also presents the NIST results for $25(\mathrm{OH}) \mathrm{D}_{\text {Total }}$ in the control and the two study materials. 
Table 1. Summary of participant and NIST results for $25(\mathrm{OH}) \mathrm{D}_{\text {Total }}(\mathrm{ng} / \mathrm{mL})$ in VitDQAP-I (Vial A), SRM 2973 (Vial B), and SRM 968d L1 (Control).

\begin{tabular}{|c|c|c|c|c|}
\hline & & VitDQAP-I & SRM 2973 & SRM 968d L1 \\
\hline Lab & Method & Vial A & Vial B & Control \\
\hline 017 & CLIA & 33.8 & 41.8 & 14.1 \\
\hline 026 & LC-MS/MS & 30.7 & 38.3 & 12.0 \\
\hline $030 a$ & RIA & 35.1 & 44.5 & 14.2 \\
\hline $056 a$ & LC-MS/MS & 33.4 & 42.7 & 12.8 \\
\hline 056b & LC-MS/MS & 30.3 & 38.1 & 12.8 \\
\hline 060 & LC-MS/MS & 28.0 & 37.0 & 12.0 \\
\hline 110 & LC-UV & 32.5 & 43.3 & 12.6 \\
\hline 116 & LC-MS/MS & 35.1 & 43.3 & 15.1 \\
\hline 119 & LC-MS/MS & 30.5 & 37.6 & $\mathrm{n} / \mathrm{r}$ \\
\hline 150 & LC-MS/MS & 28.2 & 37.1 & 12.4 \\
\hline $161 b$ & LC-MS/MS & 33.0 & 41.0 & 13.0 \\
\hline 180 & RIA & 30.4 & 36.5 & 15.1 \\
\hline 187 & LC-MS/MS & 33.8 & 44.8 & 12.1 \\
\hline 188 & CLIA & 42.9 & 50.2 & 12.3 \\
\hline 189 & LC-UV & 39.4 & 48.7 & 8.6 \\
\hline 194 & LC-MS/MS & 33.9 & 38.8 & 12.1 \\
\hline 196 & CLIA & 29.8 & 37.1 & 13.2 \\
\hline 197 & LC-MS/MS & 30.3 & 40.8 & 12.4 \\
\hline 199 & LC-MS/MS & 31.4 & 39.6 & 13.3 \\
\hline 200 & RIA & 23.0 & 27.8 & 12.7 \\
\hline $204 a$ & CLIA & 31.0 & 43.2 & 14.9 \\
\hline $204 b$ & LC-MS/MS & 30.8 & 41.5 & 12.7 \\
\hline 209 & LC-MS/MS & 34.0 & 48.8 & 12.4 \\
\hline $210 a$ & RIA & 32.1 & 40.2 & 17.4 \\
\hline $210 b$ & CLIA & 30.9 & 44.8 & $n / r$ \\
\hline 211 & LC-MS/MS & 37.8 & 49.1 & 12.6 \\
\hline 212 & LC-MS/MS & 31.9 & 42.9 & 12.8 \\
\hline $213 a$ & CLIA & 35.2 & 48.4 & 7.4 \\
\hline $213 b$ & EIA & 25.2 & 32.3 & 13.9 \\
\hline $214 a$ & RIA & 17.1 & 16.6 & 6.3 \\
\hline $214 b$ & CLIA & 29.4 & 38.1 & 13.0 \\
\hline $214 c$ & LC-MS/MS & 31.3 & 38.6 & 12.2 \\
\hline 215 & LC-MS/MS & 34.8 & 40.8 & 14.0 \\
\hline 216 & LC-MS/MS & 37.2 & 41.3 & 12.3 \\
\hline 217 & LC-MS/MS & 39.2 & 48.8 & 16.4 \\
\hline $218 a$ & CLIA & 31.1 & 40.7 & 14.0 \\
\hline $218 b$ & LC-MS/MS & 38.1 & 42.1 & 14.7 \\
\hline 220 & LC-MS/MS & 31.0 & 38.4 & 12.5 \\
\hline $221 a$ & LC-MS/MS & 30.1 & 35.3 & 14.9 \\
\hline $221 b$ & LC-UV & 34.3 & 42.7 & 38.5 \\
\hline 222 & CLIA & 35.3 & 40.1 & 15.0 \\
\hline 225 & LC-MS/MS & 32.9 & 44.6 & 13.4 \\
\hline $228 a$ & LC-MS/MS & 37.0 & 45.7 & 12.0 \\
\hline 242 & LC-MS/MS & 30.0 & 36.9 & 12.8 \\
\hline $243 a$ & LC-UV & 29.8 & 37.0 & 12.9 \\
\hline $243 b$ & LC-MS/MS & 30.0 & 37.0 & 12.6 \\
\hline 244 & LC-MS/MS & 34.0 & 40.0 & 16.0 \\
\hline 249 & LC-MS/MS & 30.4 & 41.2 & 12.8 \\
\hline 251 & LC-MS/MS & 37.0 & 54.0 & $n / r$ \\
\hline 253 & LC-MS/MS & 30.8 & 39.6 & 12.2 \\
\hline 255 & LC-MS/MS & 33.4 & 41.0 & 12.9 \\
\hline 256 & CLIA & 33.0 & 35.8 & 11.4 \\
\hline 257 & CLIA & 30.5 & 42.0 & 5.9 \\
\hline 258 & CLIA & 33.9 & 64.4 & 13.6 \\
\hline 259 & LC-MS/MS & 34.4 & 45.2 & 10.3 \\
\hline 261 & CLIA & 24.2 & 37.4 & 6.6 \\
\hline 262 & CLIA & 27.5 & 39.1 & 20.2 \\
\hline 263 & CLIA & 33.7 & 37.6 & 12.8 \\
\hline 264 & LC-MS/MS & 41.6 & 39.8 & 14.0 \\
\hline 265 & LC-MS/MS & 35.0 & 44.0 & 13.0 \\
\hline $266 a$ & LC-UV & 41.3 & 50.8 & 16.4 \\
\hline $266 b$ & EIA & 29.2 & 38.3 & 18.5 \\
\hline 267 & CLEIA & 30.4 & 39.3 & 12.4 \\
\hline
\end{tabular}

\begin{tabular}{|c|c|c|c|c|}
\hline & & VitDQAP-I & SRM 2973 & SRM 968d L1 \\
\hline & & Vial A & Vial B & Control \\
\hline \multirow{4}{*}{$=\frac{\stackrel{0}{0}}{\mathrm{D}}$} & $\mathrm{N}$ & 63 & 63 & 60 \\
\hline & Median & 32.1 & 40.8 & 12.8 \\
\hline & MADe & 2.9 & 4.1 & 1.1 \\
\hline & CV\% & 9.1 & 10 & 8.7 \\
\hline \multirow{4}{*}{$\leq \frac{\stackrel{0}{8}}{\stackrel{0}{c}}$} & $N$ & 23 & 23 & 22 \\
\hline & Median & 30.9 & 39.3 & 13.4 \\
\hline & MADe & 4.2 & 4.0 & 2.0 \\
\hline & CV\% & 14 & 10 & 15 \\
\hline \multirow{4}{*}{ 올 } & & 40 & 40 & 38 \\
\hline & Median & 33.2 & 41.1 & 12.8 \\
\hline & MADe & 3.6 & 4.0 & 0.8 \\
\hline & $\mathrm{CV} \%$ & 11 & 9.8 & 6.4 \\
\hline \multirow{4}{*}{$\sum_{j}^{0}$} & & 35 & 35 & 33 \\
\hline & Median & 33.0 & 41.0 & 12.8 \\
\hline & MADe & 3.3 & 3.9 & 0.7 \\
\hline & CV\% & 9.9 & 9.4 & 5.8 \\
\hline & NIST Value & 32.0 & 40.1 & 12.5 \\
\hline & $U$ & 0.8 & 0.8 & 0.4 \\
\hline
\end{tabular}

$\mathrm{n} / \mathrm{r}=$ not reported or not determined 
For all participant datasets, the single reported values for $25(\mathrm{OH}) \mathrm{D}_{\text {Total }}$ in VitDQAP-I (Vial A), SRM 2973 (Vial B), and SRM 968d L1 (Control) are plotted in Figure 1, Figure 2, and

Figure 3, respectively. The results from immunoassay methods are displayed with open dark blue circles (०), and the results from the LC-based methods are displayed with open light blue circles ( $)$. The results from the individual methods were sorted separately, as indicated by the $\mathrm{x}$-axis labels.

From the single reported values for all datasets for a given technique (IA or LC), the consensus median and the consensus variability $(2 \times$ MADe $)$ were determined. For both of the major techniques (IA or LC) in each figure, the solid lines (-) and (-) represent the consensus median, and the dashed lines (- - - - ) and (- - - -) represent the approximate $95 \%$ confidence interval $(2 \times$ MADe). The laboratories with results that fall between the two dashed lines are within the consensus variability area for their technique (IA or LC).

The red lines ( - ) in each figure (Figures $\mathbf{1}-\mathbf{3}$ ) represent the NIST value and its associated expanded uncertainty (i.e., value $\pm U$ ). NIST has confidence that the "true" value for each material lies within this interval. When these lines are not within the consensus ranges for each technique (IA or LC), then there may be method bias.

Specific results for each of the three study materials are summarized below. Note that the assessment is based on the actual reported values, not the lines and symbols, which have been enlarged to show detail and the laboratory number.

\section{VitDQAP-I (Vial A): Figure 1}

- For the IA results, two reported values are outside of the consensus variability range (one CLIA, one RIA).

- For the LC results, two reported values are outside of the consensus variability range (one LC$\mathrm{MS}^{\mathrm{n}}$, one LC-UV).

- The consensus median value for the IA results is slightly lower than the NIST expanded uncertainty range (red lines).

- The consensus median value for the LC results is slightly higher than the NIST expanded uncertainty range (red lines).

- The NIST expanded uncertainty range (red lines) falls within the consensus variability ranges for both IA and LC.

\section{SRM 2973 (Vial B): Figure 2}

- For the IA results, five reported values are outside the consensus variability range (three CLIA, two RIA).

- For the LC results, two reported values are outside the consensus variability range (one LC$\mathrm{MS}^{\mathrm{n}}$, one LC-UV).

- The consensus median values for both the IA and LC results are comparable to the NIST expanded uncertainty range (red lines). 


\section{SRM 968d L1 (Control): Figure 3}

- The consensus variability range is larger for the IA results than for the LC results.

- For the IA results, six reported values are outside of the consensus variability range (four CLIA, one EIA, one RIA).

- For the LC results, nine reported values are outside of the consensus variability range (six LC$\mathrm{MS}^{\mathrm{n}}$, three LC-UV).

- The consensus median value for the IA results is slightly higher than the NIST expanded uncertainty range (red lines).

- The consensus median value for the LC results is comparable to the NIST expanded uncertainty range (red lines).

- The NIST expanded uncertainty range (red lines) falls within the consensus variability range for both IA and LC. 


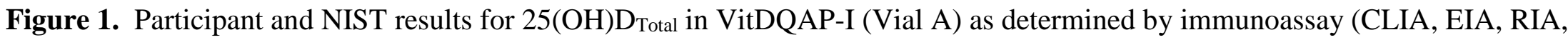
and CLEIA) and LC (LC-MS ${ }^{\mathrm{n}}$ and LC-UV) methods.

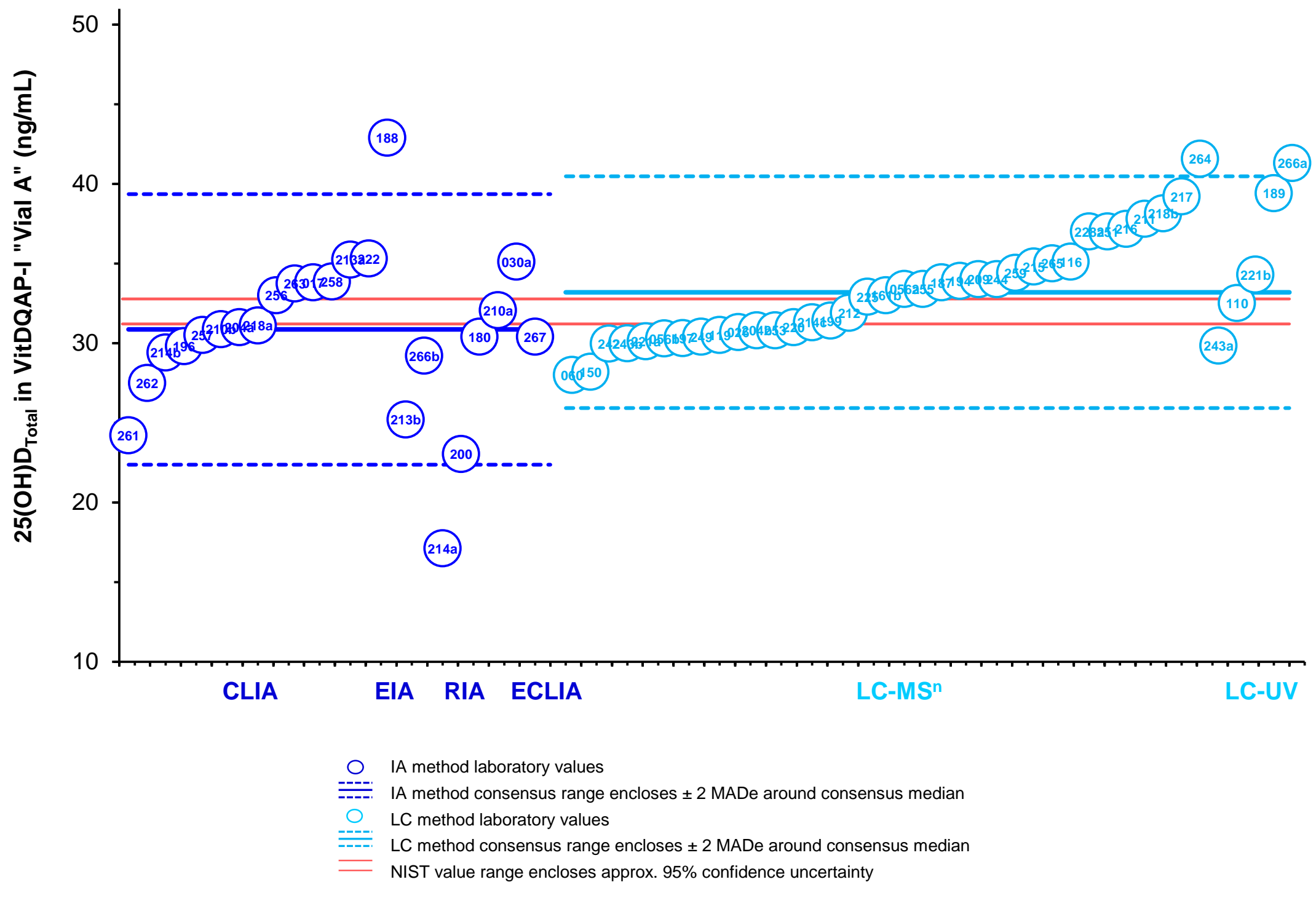


Figure 2. Participant and NIST results for $25(\mathrm{OH}) \mathrm{D}_{\text {Total }}$ in SRM 2973 (Vial B) as determined by immunoassay (CLIA, EIA, RIA, and CLEIA) and LC (LC-MS ${ }^{\mathrm{n}}$ and LC-UV) methods.

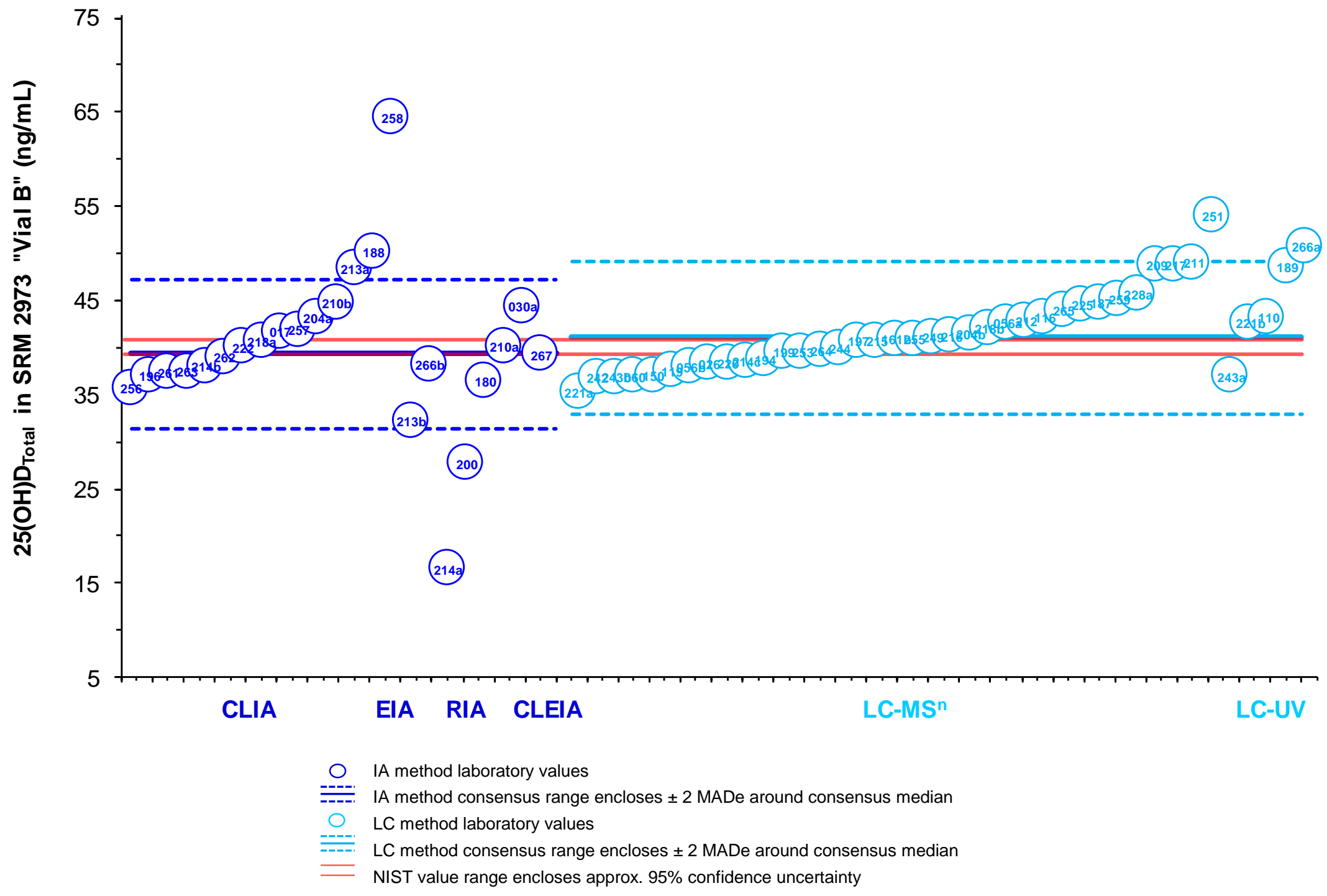


Figure 3. Participant and NIST results for $25(\mathrm{OH}) \mathrm{D}_{\text {Total }}$ in SRM $968 \mathrm{~d}$ Level 1 (Control) as determined by immunoassay (CLIA, EIA, RIA, and CLEIA) and LC (LC-MS ${ }^{\mathrm{n}}$ and LC-UV) methods.

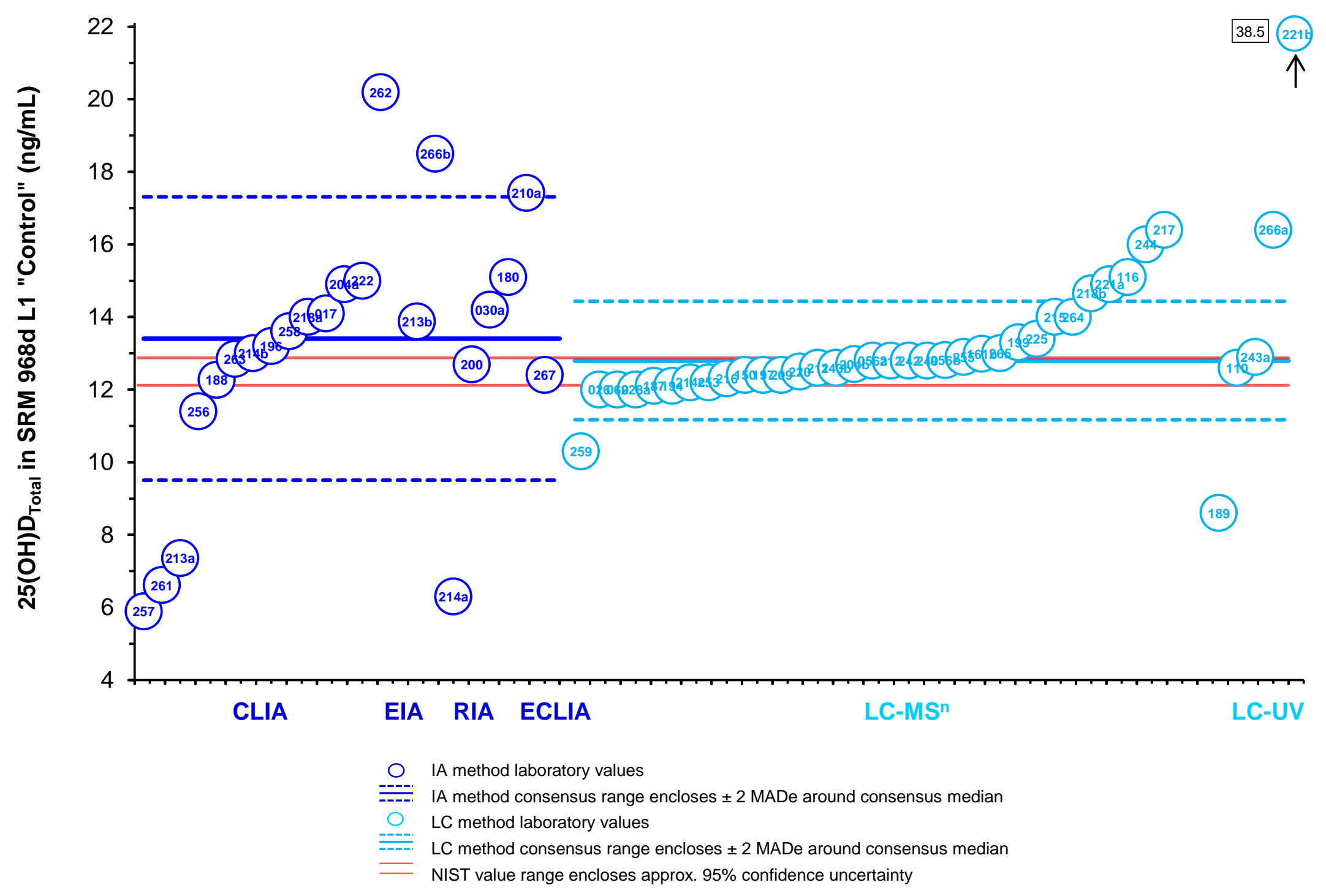


Figure 4 presents direct graphical comparisons of the $25(\mathrm{OH}) \mathrm{D}_{\text {Total }}$ results for a) VitDQAP-I (Vial A) and SRM 2973 (Vial B), and b) SRM 2973 (Vial B) and SRM 968d L1 (Control). In each plot, there are two blue consensus boxes, one for IA methods and one for LC methods (as indicated). Laboratory results that are within the consensus range for both study materials are within the blue consensus boxes. Conversely, laboratory results that fall outside of (or on the edge of) either of the consensus boxes are not included in the consensus ranges and are highlighted with their laboratory code numbers. In each plot, the NIST values for the materials are denoted with a red diamond symbol $(\diamond)$, and the Youden line $(\mathrm{y}=\mathrm{x})$ centered on the NIST value is illustrated by a red line (-) across the magnitude of the $y$-axis and $\mathrm{x}$-axis, respectively.

Specific results as assessed from the Youden comparison plots are summarized below.

VitDQAP-I (Vial A) and SRM 2973 (Vial B): Figure 4 a

- IA results that are outside of the consensus range include numbers 188, 200, 213a, 214a, and 258.

- LC results that are outside of the consensus range include numbers 251, 264, and 266.

- The Youden line runs through the center of both the IA and LC consensus boxes, illustrating that both the IA and LC results are in agreement with each other and with the NIST results for these materials.

\section{SRM 2973 (Vial B) and SRM 968d L1 (Control): Figure 4 b}

- IA results that outside of the consensus range include numbers 188, 200, 210a, 213a, 214a, 257, 258, 261, 262, and 266b

- LC results that are outside of the consensus range include numbers 116, 189, 217, 218b, 221a, 221b, 244, 259, and 266a

- The Youden line runs through the center of the LC consensus box and toward the bottom of the IA consensus box, illustrating that the LC results are in slightly better agreement with the NIST results for these materials. 
Figure 4. Youden comparison plot of the results for $25(\mathrm{OH}) \mathrm{D}_{\text {Total }}$ in a) VitDQAP-I (Vial A) and SRM 2973 (Vial B) and

b) SRM 2973 (Vial B) and SRM 968d L1 (Control) for all methods.
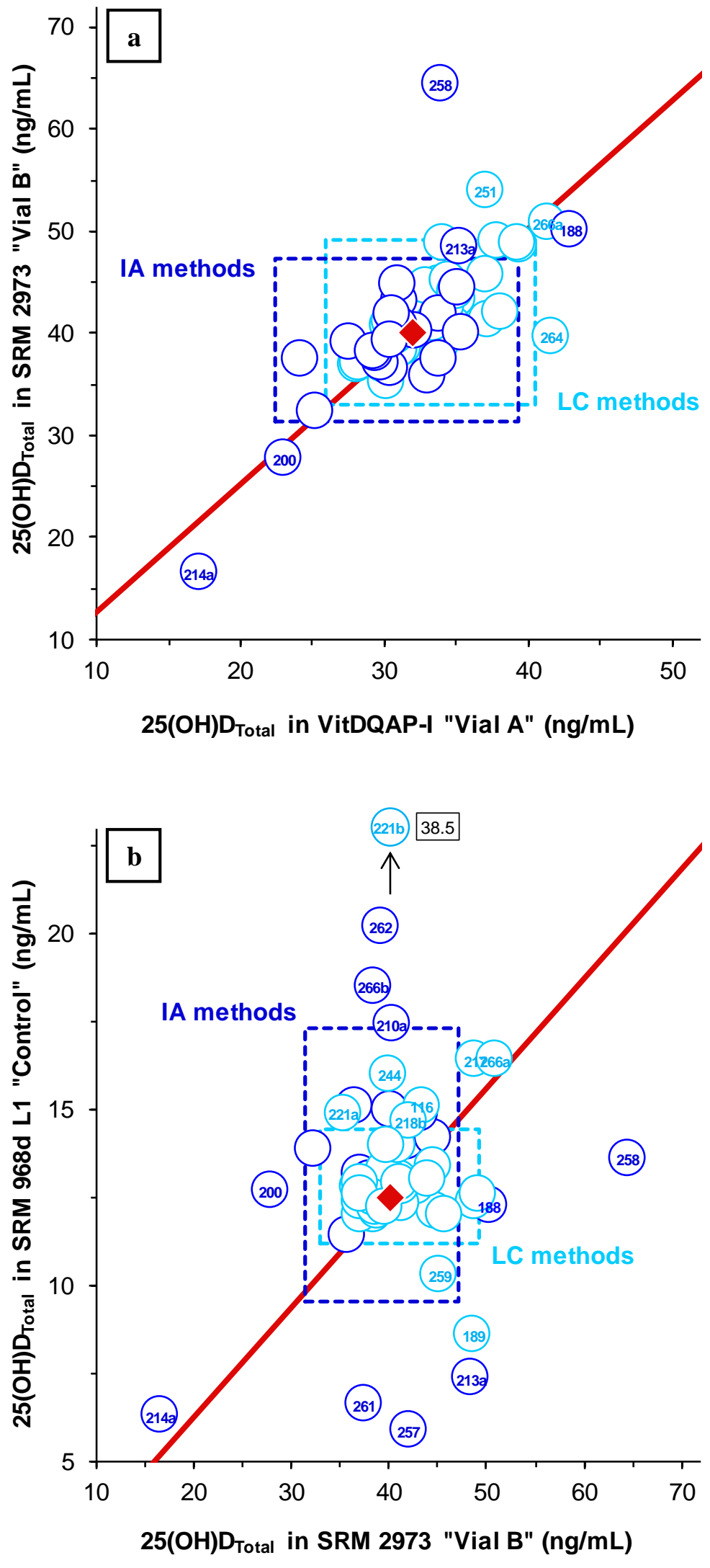


\section{LC method results for $25(\mathrm{OH}) \mathrm{D}_{3}, 25(\mathrm{OH}) \mathrm{D}_{2}$, and 3-epi-25(OH) $\mathrm{D}_{3}$}

Of the two major techniques IA and LC, only the LC methods can measure the individual vitamin D metabolites. Given that $25(\mathrm{OH}) \mathrm{D}_{\text {Total }}$ is the sum of $25(\mathrm{OH}) \mathrm{D}_{2}$ and $25(\mathrm{OH}) \mathrm{D}_{3}, \mathrm{LC}$ methods require accurate, unbiased measurements of both $25(\mathrm{OH}) \mathrm{D}_{2}$ and $25(\mathrm{OH}) \mathrm{D}_{3}$ to obtain the correct values for $25(\mathrm{OH}) \mathrm{D}_{\text {Total. }}$.

Of the 41 LC participants in the Summer 2014 comparability study, all but one lab reported values for $25(\mathrm{OH}) \mathrm{D}_{3}$, and the study results for $25(\mathrm{OH}) \mathrm{D}_{3}$ in the study materials and the control are presented in Table 2. Neither the study materials nor the control contained a significant concentration of $25(\mathrm{OH}) \mathrm{D}_{2}$, but the study results for the 12 participants that reported results for this metabolite in at least one of the materials are presented in Table 3.

Since VitDQAP-I (Vial A) and SRM 2973 (Vial B) contain relatively high concentrations of $25(\mathrm{OH}) \mathrm{D}_{3}$ (Table 2), the 3-epi-25(OH) $\mathrm{D}_{3}$ metabolite, which frequently correlates with $25(\mathrm{OH}) \mathrm{D}_{3}$, is also measureable in these materials. Ten LC participants reported values for the 3-epi-25(OH)D 3 metabolite in at least one of the materials, and the results are presented in Table 4. Because the biological significance of 3-epi-25(OH) $\mathrm{D}_{3}$ remains uncertain, this metabolite is not included in the $25(\mathrm{OH}) \mathrm{D}_{\text {Total }}$ concentration. Therefore, LC methods that do not chromatographically separate this diastereomer from $25(\mathrm{OH}) \mathrm{D}_{3}$ yield biased results for $25(\mathrm{OH}) \mathrm{D}_{3}$ and hence $25(\mathrm{OH}) \mathrm{D}_{\text {Total }}$.

The community results are summarized at the bottom of each table (Table 2 - 4), for all LC methods and for the LC-MS ${ }^{\mathrm{n}}$ methods only. These summarized results include $\mathrm{N}$, the median value, the MADe, and the CV \%. The NIST values and the expanded uncertainties are also presented at the bottom of each table. 
Table 2. Summary of LC participant data and NIST results for $25(\mathrm{OH}) \mathrm{D}_{3}(\mathrm{ng} / \mathrm{mL})$ in VitDQAP-I (Vial A), SRM 2973 (Vial B), and SRM 968d L1 (Control).

\section{5(OH) $D_{3}(\mathrm{ng} / \mathrm{mL})$}

\begin{tabular}{|c|c|}
\hline Lab & Method \\
\hline 026 & LC-MS/MS \\
\hline $056 a$ & LC-MS/MS \\
\hline 056b & LC-MS/MS \\
\hline 060 & LC-MS/MS \\
\hline 116 & LC-MS/MS \\
\hline 119 & LC-MS/MS \\
\hline 139 & LC-UV \\
\hline 150 & LC-MS/MS \\
\hline $161 b$ & LC-MS/MS \\
\hline 187 & LC-MS/MS \\
\hline 189 & LC-UV \\
\hline 194 & LC-MS/MS \\
\hline 197 & LC-MS/MS \\
\hline 199 & LC-MS/MS \\
\hline $204 b$ & LC-MS/MS \\
\hline 209 & LC-MS/MS \\
\hline 211 & LC-MS/MS \\
\hline 212 & LC-MS/MS \\
\hline $214 c$ & LC-MS/MS \\
\hline 215 & LC-MS/MS \\
\hline 216 & LC-MS/MS \\
\hline 217 & LC-MS/MS \\
\hline $218 b$ & LC-MS/MS \\
\hline 220 & LC-MS/MS \\
\hline $221 a$ & LC-MS/MS \\
\hline $221 b$ & LC-UV \\
\hline 225 & LC-MS/MS \\
\hline $228 a$ & LC-MS/MS \\
\hline 242 & LC-MS/MS \\
\hline $243 a$ & LC-UV \\
\hline $243 b$ & LC-MS/MS \\
\hline 244 & LC-MS/MS \\
\hline 249 & LC-MS/MS \\
\hline 251 & LC-MS/MS \\
\hline 253 & LC-MS/MS \\
\hline 255 & LC-MS/MS \\
\hline 259 & LC-MS/MS \\
\hline 264 & LC-MS/MS \\
\hline 265 & LC-MS/MS \\
\hline $266 \mathrm{a}$ & LC-UV \\
\hline 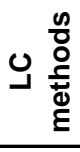 & $\begin{array}{r}\mathrm{N} \\
\text { Median } \\
\text { MADe } \\
\text { CV\% } \\
\end{array}$ \\
\hline$\sum^{0}$ & $\begin{array}{r}\mathrm{N} \\
\text { Median } \\
\text { MADe } \\
\text { CV\% }\end{array}$ \\
\hline
\end{tabular}

\begin{tabular}{|c|c|c|}
\hline VitDQAP-I & SRM 2973 & SRM 968d L1 \\
\hline Vial A & Vial B & Control \\
\hline 29.9 & 37.4 & 11.6 \\
32.7 & 41.7 & 12.6 \\
29.6 & 37.4 & 12.6 \\
27.4 & 36.4 & 11.8 \\
35.1 & 43.3 & 15.1 \\
30.5 & 37.6 & $\mathrm{n} / \mathrm{r}$ \\
46.2 & 33.7 & 12.7 \\
28.2 & 37.1 & 12.4 \\
33.0 & 41.0 & 13.0 \\
33.8 & 44.8 & 12.1 \\
39.4 & 48.7 & 8.6 \\
33.9 & 38.8 & 12.1 \\
30.3 & 40.8 & 12.4 \\
31.4 & 39.6 & 13.3 \\
30.8 & 41.5 & 12.7 \\
34.0 & 48.8 & 12.4 \\
37.8 & 49.1 & 12.6 \\
31.9 & 42.9 & 12.8 \\
31.3 & 38.6 & 12.2 \\
34.8 & 40.8 & 14.0 \\
36.4 & 40.6 & 12.2 \\
39.2 & 48.8 & 16.4 \\
38.1 & 41.8 & 14.7 \\
31.0 & 38.4 & 12.5 \\
30.1 & 35.3 & 14.9 \\
34.3 & 42.7 & 38.5 \\
32.9 & 44.6 & 13.4 \\
37.0 & 45.7 & 12.0 \\
29.5 & 36.5 & 12.8 \\
29.5 & 36.6 & 12.7 \\
29.3 & 36.4 & 12.7 \\
34.0 & 40.0 & 16.0 \\
30.4 & 41.2 & 12.8 \\
37.0 & 54.0 & $\mathrm{n} / \mathrm{r}$ \\
30.1 & 39.0 & 12.1 \\
32.7 & 40.3 & 12.7 \\
34.4 & 45.2 & 10.3 \\
41.0 & 39.2 & 13.9 \\
35.0 & 44.0 & 13.0 \\
41.3 & 50.8 & 16.4 \\
\hline 40 & 40 & 38 \\
33.0 & 40.8 & 12.7 \\
3.9 & 4.7 & 0.9 \\
12 & 12 & 6.7 \\
\hline 35 & 35 & 33 \\
32.7 & 40.8 & 12.7 \\
3.4 & 3.7 & 0.8 \\
10 & 9.1 & 6.4 \\
\hline & & \\
\hline
\end{tabular}

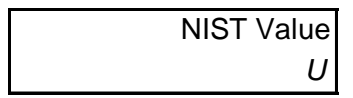

\begin{tabular}{|c|c|c|}
\hline 31.3 & 39.4 & 12.4 \\
0.8 & 0.8 & 0.4 \\
\hline
\end{tabular}


Table 3. Summary of LC participant and NIST results for $25(\mathrm{OH}) \mathrm{D}_{2}(\mathrm{ng} / \mathrm{mL})$ in VitDQAP-I (Vial A), SRM 2973 (Vial B), and SRM 968d L1 (Control).

Table 4. Summary of LC participant and NIST results for 3-epi-25(OH) $\mathrm{D}_{3}(\mathrm{ng} / \mathrm{mL})$ in VitDQAP-I (Vial A), SRM 2973 (Vial B), and SRM 968d L1 (Control).
$25(\mathrm{OH}) \mathrm{D}_{2}(\mathrm{ng} / \mathrm{mL})$

\begin{tabular}{|c|c|c|c|c|}
\hline & & VitDQAP-I & SRM 2973 & SRM 968d L1 \\
\hline Lab & Method & Vial A & Vial B & Control \\
\hline 026 & LC-MS/MS & 0.8 & 1.0 & 0.4 \\
\hline $056 a$ & LC-MS/MS & 0.8 & 1.0 & 0.2 \\
\hline 056b & LC-MS/MS & 0.7 & 0.7 & 0.2 \\
\hline 060 & LC-MS/MS & 0.6 & 0.6 & 0.2 \\
\hline 216 & LC-MS/MS & 0.7 & 0.7 & 0.2 \\
\hline $218 b$ & LC-MS/MS & 0.0 & 0.3 & 0.0 \\
\hline 242 & LC-MS/MS & 0.5 & 0.4 & $n / d$ \\
\hline $243 a$ & LC-UV & 0.5 & 0.4 & $n / d$ \\
\hline $243 b$ & LC-MS/MS & 0.5 & 0.4 & $n / d$ \\
\hline 253 & LC-MS/MS & 0.7 & 0.6 & 0.1 \\
\hline 255 & LC-MS/MS & 0.7 & 0.7 & 0.2 \\
\hline 264 & LC-MS/MS & 0.6 & 0.6 & 0.1 \\
\hline$\stackrel{\infty}{\pi}$ & $\mathrm{N}$ & 12 & 12 & 9 \\
\hline 08 & Median & 0.7 & 0.6 & 0.2 \\
\hline త气 & MADe & 0.1 & 0.2 & 0.1 \\
\hline & $\mathrm{CV} \%$ & 22 & 31 & 37 \\
\hline & $\mathrm{N}$ & 11 & 11 & 9 \\
\hline$\sum^{\infty}$ & Median & 0.7 & 0.6 & 0.2 \\
\hline ड் & MADe & 0.1 & 0.1 & 0.1 \\
\hline ل & $\mathrm{CV} \%$ & 15 & 20 & 37 \\
\hline & NIST Value & 0.68 & 0.65 & $0.1^{*}$ \\
\hline & $U$ & 0.06 & 0.02 & --- \\
\hline
\end{tabular}

\section{3-epi-25(OH)D $3(\mathrm{ng} / \mathrm{mL})$}

\begin{tabular}{|c|c|c|c|c|}
\hline & VitDQAP-I & SRM 2973 & SRM 968d L1 \\
\hline Lab & Method & Vial A & Vial B & Control \\
\hline 026 & LC-MS/MS & 2.7 & 2.4 & 0.7 \\
\hline $056 a$ & LC-MS/MS & 1.8 & 3.6 & 1.3 \\
\hline 060 & LC-MS/MS & 1.8 & 2.4 & 0.7 \\
\hline 150 & LC-MS/MS & 2.0 & 3.0 & $<2$ \\
\hline 216 & LC-MS/MS & 2.0 & 2.3 & 0.7 \\
\hline 242 & LC-MS/MS & 1.5 & 1.7 & 0.6 \\
\hline $243 a$ & LC-UV & 1.5 & 1.7 & 0.7 \\
\hline $243 b$ & LC-MS/MS & 1.4 & 1.8 & 0.6 \\
\hline 249 & LC-MS/MS & 1.5 & 1.8 & 0.5 \\
\hline 253 & LC-MS/MS & 1.9 & 2.1 & 0.7 \\
\hline & $\mathrm{N}$ & 10 & 10 & 9 \\
\hline 0 0 & Median & 1.8 & 2.2 & 0.70 \\
\hline コ宅 & MADe & 0.4 & 0.6 & 0.07 \\
\hline & $\mathrm{CV} \%$ & 20 & 29 & 11 \\
\hline & & 9 & 9 & 8 \\
\hline$\sum_{\sum}^{\infty}$ & Median & 1.8 & 2.3 & 0.70 \\
\hline j. & MADe & 0.2 & 0.7 & 0.08 \\
\hline ב & CV\% & 13 & 32 & 12 \\
\hline & NIST Value & 1.7 & 2.1 & 0.65 \\
\hline & $U$ & 0.1 & 0.1 & 0.03 \\
\hline
\end{tabular}




\section{Discussion of the Summer 2014 Comparability Study Results}

In the Summer 2014 study of the VitDQAP, $25(\mathrm{OH}) \mathrm{D}_{3}$ is the predominant vitamin D metabolite contributing to $25(\mathrm{OH}) \mathrm{D}_{\text {Total }}$ in the two study materials and the control material, which is consistent with most materials evaluated in the VitDQAP. However, the two study materials VitDQAP-I (Vial A) and SRM 2973 (Vial B) both contain relatively high levels of $25(\mathrm{OH}) \mathrm{D}_{3}$, with NIST values of $31.3 \mathrm{ng} / \mathrm{mL} \pm 0.8 \mathrm{ng} / \mathrm{mL}$ and $39.4 \mathrm{ng} / \mathrm{mL} \pm 0.8 \mathrm{ng}, \mathrm{mL}$, respectively. SRM 2973 (Vial B) contains the highest concentration of $25(\mathrm{OH}) \mathrm{D}_{3}$ of any study materials evaluated in the VitDQAP to date.

The consensus variabilities for $25(\mathrm{OH}) \mathrm{D}_{\text {Total }}$ determined by the IA and $\mathrm{LC}$ techniques differ for SRM 968d L1 (Control), with values of $15 \%$ and $6.4 \%$, respectively. When the IA and LC results for SRM 968d L1 (Control) are compared to the results from the previous two studies of the VitDQAP, the consensus variability for the LC methods has remained remarkably consistent around $6 \%$ while the consensus variability for the IA methods has fluctuated between $6 \%$ and $18 \%$, indicating that IA methods are in less control. However, the IA variability for the VitDQAP-I (Vial A) and SRM 2973 (Vial B) study materials of $14 \%$ and $10 \%$, respectively, indicate that the IA method performance is relatively consistent for different materials/matrices and $25(\mathrm{OH}) \mathrm{D}_{3}$ concentrations. Conversely, the LC method variability of $11 \%$ and $10 \%$, respectively, for the two study materials VitDQAP-I (Vial A) and SRM 2973 (Vial B) is somewhat higher than for SRM 968d L1 (Control), but still exhibits general consistency with performance on the blinded study samples containing predominantly $25(\mathrm{OH}) \mathrm{D}_{3}$ evaluated in previous studies.

The participant performance in the Summer 2014 study is generally consistent with performance in the eight prior studies, indicating that the relatively high levels of $25(\mathrm{OH}) \mathrm{D}_{3}$ and hence $25(\mathrm{OH}) \mathrm{D}_{\text {Total }}$ in the two study samples do not pose a particular measurement challenge. To date, the most significant variability in the participant results arose from study samples that contain relatively high levels of the $25(\mathrm{OH}) \mathrm{D}_{2}$ and 3-epi-25(OH) $\mathrm{D}_{3}$ metabolites. 
Appendix A-1. Summary of immunoassay methods as reported by the study participants.

\begin{tabular}{|c|c|c|c|}
\hline $\begin{array}{l}\text { Laboratory } \\
\text { Number }\end{array}$ & IA Method & Sample Preparation & Vendor/kit* \\
\hline 17 & CLIA & $\mathrm{n} / \mathrm{r}$ & A \\
\hline $30 a$ & RIA & Samples were extracted with acetonitrile & B \\
\hline 180 & RIA & Samples were extracted with acetonitrile & B \\
\hline 188 & CLIA & $\mathrm{n} / \mathrm{r}$ & C \\
\hline 196 & CLIA & No sample preparation required & A \\
\hline 200 & RIA & Samples were extracted & $B$ \\
\hline $204 a$ & CLIA & $\mathrm{n} / \mathrm{r}$ & A \\
\hline $210 a$ & RIA & Sample was extracted with acetonitrile & $B$ \\
\hline $210 b$ & CLIA & $\mathrm{n} / \mathrm{r}$ & $\mathrm{D}$ \\
\hline $213 a$ & CLIA & Sample was thawed and gently mixed prior to analysis & $\mathrm{D}$ \\
\hline $213 b$ & EIA & $\begin{array}{l}\text { Samples, calibrators, and controls processed per } \\
\text { manufacturer's protocol }\end{array}$ & $\mathrm{E}$ \\
\hline $214 a$ & RIA & $\mathrm{n} / \mathrm{r}$ & $\mathrm{F}$ \\
\hline $214 b$ & CLIA & $\mathrm{n} / \mathrm{r}$ & A \\
\hline $218 a$ & CLIA & Direct analysis & $n / r$ \\
\hline 222 & CLIA & $\mathrm{n} / \mathrm{r}$ & $\mathrm{C}$ \\
\hline 256 & CLIA & $\mathrm{n} / \mathrm{r}$ & A \\
\hline 257 & CLIA & Sample was thawed at room temperature until analysis & $\mathrm{D}$ \\
\hline 258 & CLIA & $\mathrm{n} / \mathrm{r}$ & G \\
\hline 261 & CLIA & No sample preparation required & G \\
\hline 262 & CLIA & $\mathrm{n} / \mathrm{r}$ & $\mathrm{H}$ \\
\hline 263 & EIA & On board displacement & 1 \\
\hline $266 b$ & EIA & $n / r$ & $E$ \\
\hline 267 & CLEIA & $n / r$ & $\mathrm{~J}$ \\
\hline
\end{tabular}

$\mathrm{n} / \mathrm{r}=$ not reported

*NIST cannot endorse or recommend commercial products, therefore individual vendors/kits are indicated with a unique letter but not identified 
Appendix A-2. Summary of LC-MS ${ }^{\mathrm{n}}$ methods as reported by the study participants.

\begin{tabular}{|c|c|c|c|c|}
\hline $\begin{array}{l}\text { Laboratory } \\
\text { Number }\end{array}$ & $\begin{array}{c}\text { Internal } \\
\text { Standard (IS) }\end{array}$ & Sample Preparation & Chromatographic Conditions & Detection: MRM ions \\
\hline 26 & $\begin{array}{l}25(\mathrm{OH}) \mathrm{D}_{2}-d_{6} \text { and } \\
25(\mathrm{OH}) \mathrm{D}_{3}-d_{6}\end{array}$ & Liquid-liquid extraction method & $\begin{array}{l}\text { PFP column }(100 \mathrm{~mm} \times 3.2 \mathrm{~mm}) \\
\text { isocratic elution with } 82 \% \\
\text { methanol } / 18 \% \text { water; } \\
\text { flow } 0.4 \mathrm{~mL} / \mathrm{min}\end{array}$ & $\begin{array}{l}25(\mathrm{OH}) \mathrm{D}_{3} 401 / 365 \\
25(\mathrm{OH}) \mathrm{D}_{2} 413 / 355 \\
\text { 3-epi-25(OH) } \mathrm{D}_{3} 401 / 365\end{array}$ \\
\hline $56 a$ & $\begin{array}{c}25(\mathrm{OH}) \mathrm{D}_{2}-d_{3} \\
25(\mathrm{OH}) \mathrm{D}_{3}-d_{6} \\
\text { 3-epi-25(OH) } \mathrm{D}_{3}-d_{3}\end{array}$ & $\begin{array}{l}\text { Samples were extracted with } \\
\text { hexane, evaporated, then } \\
\text { reconstituted with } 69 \% \text { methanol }\end{array}$ & $\begin{array}{l}\text { PFP column }(100 \mathrm{~mm} \times 2.1 \mathrm{~mm} \text {; } \\
1.9 \mu \mathrm{m}) \text {; isocratic elution; } \\
\text { flow } 0.4 \mathrm{~mL} / \mathrm{min}\end{array}$ & 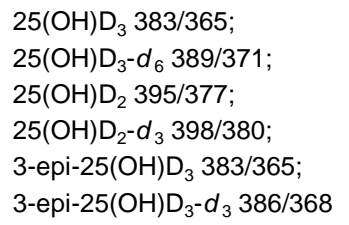 \\
\hline $56 b$ & $\mathrm{n} / \mathrm{r}$ & $\mathrm{n} / \mathrm{r}$ & $\mathrm{n} / \mathrm{r}$ & $\mathrm{n} / \mathrm{r}$ \\
\hline 60 & $25(\mathrm{OH}) \mathrm{D}_{3}-d_{6}$ & $\begin{array}{l}\text { IS was added, and then samples } \\
\text { were extracted with acetonitrile, } \\
\text { evaporated, and reconstituted } \\
\text { with } 90 \% \text { methanol } / 10 \% \text { water }\end{array}$ & $\begin{array}{l}\text { PFP column }(100 \mathrm{~mm} \times 3.0 \mathrm{~mm} \text {; } \\
2.6 \mu \mathrm{m}) ; \text { gradient with water, } \\
\text { methanol and acetonitrile }(0.05 \% \\
\text { formic acid })\end{array}$ & $\begin{array}{l}\text { APPI } \\
25(\mathrm{OH}) \mathrm{D}_{3} 383 / 211 \\
25(\mathrm{OH}) \mathrm{D}_{3}-d_{6} 389 / 211 \\
25(\mathrm{OH}) \mathrm{D}_{2} 413 / 355 \\
\text { 3-epi-25(OH) } \mathrm{D}_{3} 401 / 383\end{array}$ \\
\hline 116 & $25(\mathrm{OH}) \mathrm{D}_{3}-d_{6}$ & $\begin{array}{l}\text { Serum proteins were precipitated } \\
\text { with methanol }\end{array}$ & $\begin{array}{l}\text { Online SPE; reversed-phase } \\
\text { column; isocratic elution with } \\
95 \% \text { methanol } / 5 \% \text { water; } \\
\text { flow } 0.6 \mathrm{~mL} / \mathrm{min}\end{array}$ & $\begin{array}{l}25(\mathrm{OH}) \mathrm{D}_{3} 383 / 211 \\
25(\mathrm{OH}) \mathrm{D}_{3}-d_{6} 389 / 211 \\
25(\mathrm{OH}) \mathrm{D}_{2} 395 / 269\end{array}$ \\
\hline 119 & $25(\mathrm{OH}) \mathrm{D}_{3}-d_{6}$ & $\begin{array}{l}\text { Samples were mixed with ethanol } \\
\text { containing the IS, equilibrated, } \\
\text { mixed, extracted with hexane, } \\
\text { evaporated, and reconstituted in } \\
\text { methanol }\end{array}$ & $\begin{array}{l}\text { C18 column }(150 \mathrm{~mm} \times 3.0 \mathrm{~mm} \text {; } \\
2.7 \mu \mathrm{m}) \text {; Gradient with water and } \\
\text { methanol }(0.1 \% \text { formic acid })\end{array}$ & $\begin{array}{l}25(\mathrm{OH}) \mathrm{D}_{3} 401 / 383 \\
25(\mathrm{OH}) \mathrm{D}_{3}-d_{6} 407 / 371 \text { and } \\
407 / 389 ; \\
25(\mathrm{OH}) \mathrm{D}_{2} 395 / 209 \text { and } \\
395 / 251\end{array}$ \\
\hline 150 & $\begin{array}{c}25(\mathrm{OH}) \mathrm{D}_{2}-d_{6} \text { and } \\
25(\mathrm{OH}) \mathrm{D}_{3}-d_{3}\end{array}$ & $\begin{array}{l}\text { Sample }(200 \mu \mathrm{L}) \text { was mixed with } \\
\text { IS solution, liquid-liquid extracted, } \\
\text { centrifuged, supernatant } \\
\text { evaporated, and reconstitued in } \\
\text { mobile phase }\end{array}$ & $\begin{array}{l}\text { PFP column }(100 \mathrm{~mm} \times 3.0 \mathrm{~mm} \text {; } \\
2.6 \mu \mathrm{m}) \text {; isocratic separation with } \\
74 \% \text { methanol } / 26 \% \text { water } \\
(2 \mathrm{mmol} / \mathrm{L} \text { ammonium acetate, } \\
0.1 \% \text { formic acid); } \\
\text { flow } 0.5 \mathrm{~mL} / \mathrm{min}\end{array}$ & $\begin{array}{l}25(\mathrm{OH}) \mathrm{D}_{3} 401 / 383,401 / 365 \\
25(\mathrm{OH}) \mathrm{D}_{2} 413 / 395,413 / 365\end{array}$ \\
\hline $161 b$ & $25(\mathrm{OH}) \mathrm{D}_{3}-d_{6}$ & Protein precipitation & $\begin{array}{l}\text { Reversed-phase column }(50 \mathrm{~mm} \times \\
2.1 \mathrm{~mm} ; 2.6 \mu \mathrm{m}) \text {; gradient with } \\
\text { methanol and water }(0.1 \% \text { formic } \\
\text { acid); flow } 0.5 \mathrm{~mL} / \mathrm{min}\end{array}$ & $\mathrm{APCl}$ \\
\hline 187 & $\mathrm{n} / \mathrm{r}$ & SPE & $\begin{array}{l}\text { C18 column }(50 \mathrm{~mm} \times 2.1 \mathrm{~mm} \text {; } \\
3 \mu \mathrm{m}) \text {; gradient with methanol and } \\
\text { water }\end{array}$ & $\begin{array}{l}25(\mathrm{OH}) \mathrm{D}_{2} 413 / 395 \\
25(\mathrm{OH}) \mathrm{D}_{3} 401 / 383\end{array}$ \\
\hline 194 & $25(\mathrm{OH}) \mathrm{D}_{3}-d_{6}$ & $\begin{array}{l}\text { Proteins precipitated with } \\
\text { acetonitrile, top layer removed, } \\
\text { evaporated, and reconstituted } \\
\text { with methanol }\end{array}$ & $\begin{array}{l}\text { C8 column }(50 \mathrm{~mm} \times 2 \mathrm{~mm}) \text {; } \\
\text { isocratic elution with } 70 \% \\
\text { acetonitrile/ } 30 \% \text { water; } \\
\text { flow } 0.7 \mathrm{~mL} / \mathrm{min}\end{array}$ & $\begin{array}{l}25(\mathrm{OH}) \mathrm{D}_{2} 395 / 119 \\
25(\mathrm{OH}) \mathrm{D}_{3} 383 / 211\end{array}$ \\
\hline 197 & $25(\mathrm{OH}) \mathrm{D}_{3}-d_{6}$ & $\begin{array}{l}\text { Precipitating agent added ( } 200 \mu \mathrm{L} \\
\text { with } 20 \mathrm{ng} \text { IS) to each serum } \\
\text { sample }(200 \mu \mathrm{L}) \text {, calibrator and } \\
\text { control sample followed by mixing, } \\
\text { centrifugation, and analysis }\end{array}$ & $\begin{array}{l}\mathrm{C} 18 \text { column }(50 \mathrm{~mm} \times 4.6 \mathrm{~mm} \text {; } \\
5 \mu \mathrm{m}) \text {; column temp } 45^{\circ} \mathrm{C} \text {; gradient } \\
\text { with water and methanol; } \\
\text { flow } 1.0 \mathrm{~mL} / \mathrm{min}\end{array}$ & $\mathrm{n} / \mathrm{r}$ \\
\hline 199 & proprietary & proprietary & proprietary & proprietary \\
\hline $204 b$ & $\begin{array}{c}25(\mathrm{OH}) \mathrm{D}_{2}-d_{3} \\
25(\mathrm{OH}) \mathrm{D}_{3}-d_{6} \\
\text { 3-epi-25(OH) } \mathrm{D}_{3}-d_{3}\end{array}$ & $\begin{array}{l}\text { Protein crash with } 73 \% \text { methanol } \\
\text { followed by liquid-liquid extraction } \\
\text { with hexane, centrifugation, } \\
\text { evaporation, and reconstitution in } \\
\text { mobile phase }\end{array}$ & $\begin{array}{l}\text { PFP column }(100 \mathrm{~mm} \times 2.1 \mathrm{~mm} \text {; } \\
1.9 \mu \mathrm{m}) \text {; column temperature } 30{ }^{\circ} \mathrm{C} \text {; } \\
\text { isocratic elution with } 73 \% \\
\text { methanol } / 27 \% \text { water; } \\
\text { flow } 0.4 \mathrm{~mL} / \mathrm{min}\end{array}$ & $\begin{array}{l}\text { APCl } \\
25(\mathrm{OH}) D_{3} 383 / 365,383 / 257 ; \\
25(\mathrm{OH}) D_{2} 395 / 377,395 / 209 ; \\
\text { 3-epi-25(OH)D } D_{3} 383 / 365 \\
383 / 257\end{array}$ \\
\hline
\end{tabular}




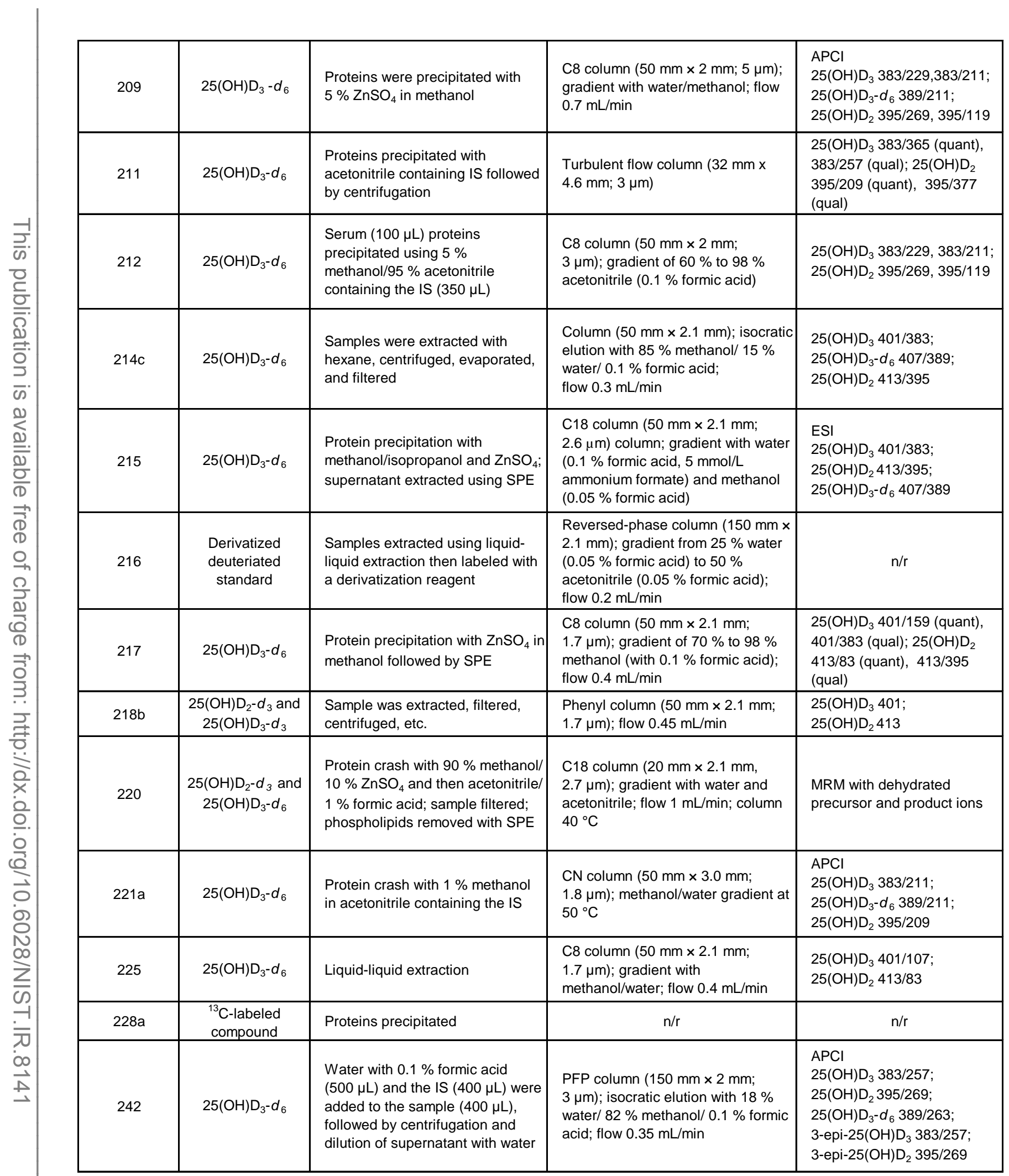




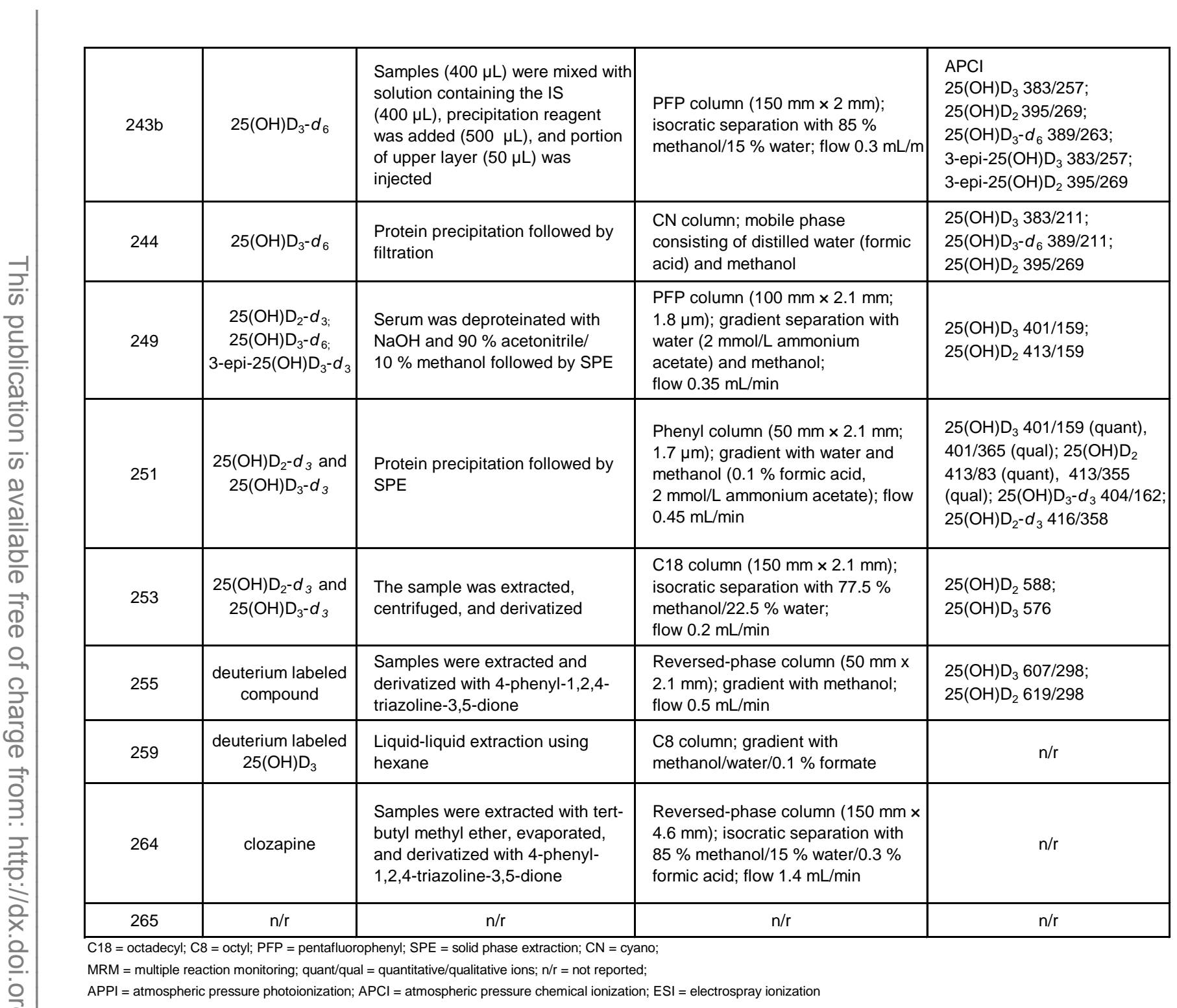


Appendix A-3. Summary of LC-UV methods as reported by study participants.

\begin{tabular}{|c|c|c|c|c|}
\hline $\begin{array}{l}\text { Laboratory } \\
\text { Number }\end{array}$ & $\begin{array}{c}\text { Internal } \\
\text { Standard (IS) }\end{array}$ & Sample Preparation & Chromatographic Conditions & Wavelength \\
\hline 110 & $\mathrm{n} / \mathrm{a}$ & $\begin{array}{l}\text { Samples }(500 \mu \mathrm{L}) \text { were mixed with } \\
\text { ethanol }(500 \mu \mathrm{L}) \text {, extracted twice } \\
\text { with hexane/methylene chloride } \\
(5: 1), \text { evaporated, and } \\
\text { reconstituted }\end{array}$ & $\begin{array}{l}\text { C18 column }(2.1 \mathrm{~mm} \times 100 \mathrm{~mm} \text {; } \\
1.8 \mu \mathrm{m}) \text {; gradient with } \\
\text { acetonitrile/methanol }(85: 15) \text { and } \\
\text { isopropanol }(100 \%)\end{array}$ & $267 \mathrm{~nm}$ \\
\hline 139 & proprietary & $\begin{array}{l}\text { The sample was extracted, } \\
\text { centrifuged, and injected }\end{array}$ & $\begin{array}{l}\text { Reversed-phase column heated to } \\
40^{\circ} \mathrm{C} \text {, isocratic separation with } \\
\text { proprietary mobile phase; flow } \\
1 \mathrm{~mL} / \mathrm{min}\end{array}$ & $264 \mathrm{~nm}$ \\
\hline 189 & unidentified & $\begin{array}{l}\text { Protein precipitation followed by } \\
\text { SPE }\end{array}$ & $\begin{array}{l}\text { Reversed-phase column }(150 \mathrm{~mm} \times \\
4.6 \mathrm{~mm}) \text {; isocratic separation; flow } \\
0.7 \mathrm{~mL} / \mathrm{min}\end{array}$ & $265 \mathrm{~nm}$ \\
\hline $221 b$ & laurophenone & $\begin{array}{l}\text { Protein crash with acetonitrile } \\
\text { solution containing IS, followed by } \\
\text { SPE, elution with } \\
\text { methanol/acetonitrile solution, } \\
\text { evaporation, and reconstitution } \\
\text { with acetonitrile }\end{array}$ & $\begin{array}{l}\mathrm{CN} \text { column }(150 \mathrm{~mm} \times 5 \mathrm{~mm} \text {; } \\
3.5 \mu \mathrm{m}) ; \text { elution with } \\
\text { methanol/water/formic acid; column } \\
\text { temperature } 47^{\circ} \mathrm{C}\end{array}$ & $275 \mathrm{~nm}$ \\
\hline $243 a$ & dodecanophenone & $\begin{array}{l}\text { Samples }(400 \mu \mathrm{L}) \text { were mixed with } \\
\text { solution containing the IS ( } 400 \\
\mu \mathrm{L}) \text {, precipitation reagent was } \\
\text { added }(500 \mu \mathrm{L}) \text {, and portion of } \\
\text { upper layer }(50 \mu \mathrm{L}) \text { was injected }\end{array}$ & $\begin{array}{l}\text { C18 column }(100 \mathrm{~mm} \times 3 \mathrm{~mm}) \text {; } \\
\text { isocratic elution with water and } \\
\text { isobutanol; flow } 1.2 \mathrm{~mL} / \mathrm{min}\end{array}$ & $264 \mathrm{~nm}$ \\
\hline $266 a$ & alpha calcidol & $\begin{array}{l}\text { Proteins precipitated with } \\
\text { acetonitrile and methanol, } \\
\text { extracted with SPE, eluted with } \\
\text { ethyl acetate, evaporated, and } \\
\text { reconstituted in acetonitrile }\end{array}$ & $\begin{array}{l}\text { C18 column }(4.6 \mathrm{~mm} \times 150 \mathrm{~mm} \text {; } \\
2.5 \mu \mathrm{m}) ; \text { gradient with acetonitrile } \\
\text { and methanol; flow } 0.5 \mathrm{~mL} / \mathrm{min}\end{array}$ & $265 \mathrm{~nm}$ \\
\hline
\end{tabular}

$\mathrm{C} 18$ = octadecyl; SPE = solid phase extraction; $\mathrm{CN}$ = cyano; $\mathrm{n} / \mathrm{a}=$ not applicable 
Appendix B. Raw participant data and NIST results for $25(\mathrm{OH}) \mathrm{D}_{2}, 25(\mathrm{OH}) \mathrm{D}_{3}$, $25(\mathrm{OH}) \mathrm{D}_{\text {Total }}$, and 3-epi$25(\mathrm{OH}) \mathrm{D}_{3}$, and in VitDQAP-I (Vial A), SRM 2973 (Vial B), and SRM 968d L1 (Control).

\begin{tabular}{|c|c|c|c|c|c|c|c|c|c|c|c|c|c|}
\hline & \multicolumn{3}{|c|}{$25(\mathrm{OH}) \mathrm{D}_{2}(\mathrm{ng} / \mathrm{mL})$} & \multicolumn{3}{|c|}{$25(\mathrm{OH}) \mathrm{D}_{3}(\mathrm{ng} / \mathrm{mL})$} & \multicolumn{3}{|c|}{$25(\mathrm{OH}) \mathrm{D}_{\text {Totat }}(\mathrm{ng} / \mathrm{mL})$} & \multicolumn{3}{|c|}{ 3-epi-25(OH) $D_{3}(\mathrm{ng} / \mathrm{mL})$} \\
\hline & & VitDaAP-1 & SRM 2973 & \begin{tabular}{|l|} 
SRM 968d L1 \\
\end{tabular} & $\begin{array}{l}\text { VitDDAP-1 } \\
\text { VitioA- }\end{array}$ & SRM 2973 & SRM 968d L1 & $\begin{array}{l}\text { VitDoAP-1 } \\
\text { VIVaA- }\end{array}$ & SRM 2973 & SRM 968d L1 & $\begin{array}{ll}\text { VitDQAP-I } \\
\text { Vitvaid }\end{array}$ & SRM 2973 & $\begin{array}{ll}\text { SRM 968d L1 } \\
\text { Control }\end{array}$ \\
\hline \begin{tabular}{|l} 
Lab \\
017
\end{tabular} & $\begin{array}{ll}\text { Method } \\
\text { CLA }\end{array}$ & $\begin{array}{ll}\text { Vial A } \\
\text { nala }\end{array}$ & $\begin{array}{l}\text { Vial } B \\
n / a\end{array}$ & & & $\begin{array}{l}\text { Vial B } \\
\text { nala }\end{array}$ & \begin{tabular}{|l|l|} 
Control \\
n/a
\end{tabular} & $\begin{array}{ll}\text { Viala } \\
33.8 \\
\end{array}$ & $\begin{array}{l}\text { Vial B } \\
41.8 \\
\end{array}$ & $\begin{array}{l}\text { Control } \\
14.1\end{array}$ & $\begin{array}{l}\text { Vial } \mathrm{A} \\
\mathrm{n} / \mathrm{a}\end{array}$ & $\begin{array}{l}\text { Vial } B \\
\text { nala }\end{array}$ & $\begin{array}{l}\text { Control } \\
\text { n/a }\end{array}$ \\
\hline $\begin{array}{l}017 \\
026\end{array}$ & $\begin{array}{l}\text { LC-MSMS } \\
\text { LCA }\end{array}$ & $\begin{array}{l}\text { n/a } \\
0.8\end{array}$ & $\begin{array}{l}n / 2 \\
1.0\end{array}$ & $\begin{array}{l}n / a \\
0.4\end{array}$ & $\begin{array}{r}\text { nna } \\
29.9\end{array}$ & $\begin{array}{l}n \text { na } \\
37.4\end{array}$ & $\begin{array}{l}\mathrm{n} / \mathrm{a} \\
11.6\end{array}$ & $\begin{array}{l}33.8 \\
307\end{array}-7$ & $\begin{array}{l}41.8 \\
38.3\end{array}$ & $\begin{array}{l}14.1 \\
12.0\end{array}$ & $\begin{array}{l}n / a \\
27\end{array}$ & $\begin{array}{l}n / a \\
24 \\
24\end{array}$ & \\
\hline & $\mathrm{Rl}$ & & no & $\begin{array}{l}0.4 \\
\text { n/a }\end{array}$ & n/a & $\begin{array}{l}0.4 \\
\mathrm{n} / \mathrm{a}\end{array}$ & $\mathrm{n} / \mathrm{a}$ & $\begin{array}{l}30.1 \\
35.1\end{array}$ & $\begin{array}{l}38.3 \\
44.5\end{array}$ & $\begin{array}{l}12.0 \\
14.2\end{array}$ & $\begin{array}{l}2.1 \\
\mathrm{n} / \mathrm{a}\end{array}$ & $\begin{array}{l}2.4 \\
n / a\end{array}$ & n/a \\
\hline 056a & LC-MSMS & 0.8 & 1.0 & 0.2 & 32.7 & 41.7 & 12.6 & 33.4 & 42.7 & 12.8 & 1.8 & 3.6 & 1.3 \\
\hline $\begin{array}{l}0566 \\
060\end{array}$ & $\begin{array}{l}\text { LC.MSIMS } \\
\text { LC-MSMS }\end{array}$ & 0.7 & $\begin{array}{l}0.7 \\
0.6\end{array}$ & $\begin{array}{l}0.2 \\
0.2\end{array}$ & $\begin{array}{l}29.6 \\
27.4\end{array}$ & $\begin{array}{l}37.4 \\
36.4\end{array}$ & $\begin{array}{l}12.6 \\
11.8\end{array}$ & $\begin{array}{l}30.3 \\
28.0\end{array}$ & $\begin{array}{l}38.1 \\
37.0\end{array}$ & 12.8 & $n / r$ & n/r & $n / r$ \\
\hline 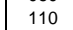 & $\begin{array}{l}\text { LC.UV } \\
\text { LC UV }\end{array}$ & & & & & & & & & & & & $\begin{array}{l}0 . / \\
n / r\end{array}$ \\
\hline 116 & LC-MSMS & $<3.3$ & $<3.3$ & $<3.3$ & 35.1 & 43.3 & 15.1. & 35.1 & 43.3 & 15.1 & $<4.0$ & $<4.0$ & $<4.0$ \\
\hline 119 & LC-MSMS & n/d & n/d & $n / d$ & 30.5 & 37.6 & $\mathrm{n} / \mathrm{r}$ & 30.5 & 37.6 & $n / r$ & $\mathrm{n} / \mathrm{r}$ & $n / r$ & $n / r$ \\
\hline $\begin{array}{l}139 \\
130\end{array}$ & LC.UV & 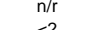 & nir & 旾/r & $\begin{array}{l}46.2 \\
462\end{array}$ & $\begin{array}{l}33.7 \\
337\end{array}$ & $\begin{array}{l}12.7 \\
12.4\end{array}$ & 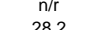 & 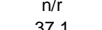 & 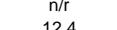 & 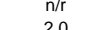 & 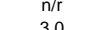 & 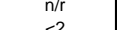 \\
\hline 180 & RIA & $\mathrm{n} / \mathrm{a}$ & $n / a$ & 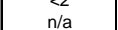 & 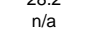 & nala & 列 & & 36.5 & $\begin{array}{l}1.41 \\
15.1\end{array}$ & n/a & 管la & $\begin{array}{l}e^{2} 2 \\
n / a\end{array}$ \\
\hline 187 & LC-MSMS & $<1.5$ & $<1.5$ & $<1.5$ & 33.8 & 44.8 & 12.1 & 33.8 & 44.8 & 12.1 & $n / r$ & $\mathrm{n} / \mathrm{r}$ & $\mathrm{n} / \mathrm{s}$ \\
\hline & & n/a & n/a & n/a & n/a & nala & n/a & ${ }^{42.9} .9$ & 50.2 & 12.3 & n/a & n/a & n/a \\
\hline & LC-MSMS & $<7.0$ & 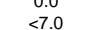 & $<7.0$ & 33.9 & 38.8 & 121 & 33.9 & 388 & 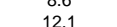 & $n / r$ & 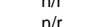 & $\begin{array}{l}n / r \\
n / r \\
n\end{array}$ \\
\hline 196 & CLA & $n / a$ & $n / a$ & n/a & n/a & $n / a$ & $n / a$ & $29.8 \mathrm{Y}-2 \mathrm{C}$ & 37.1 & 13.2 & $n / a$ & n/a & $\begin{array}{l}n+a \\
n / a\end{array}$ \\
\hline 197 & LC-MSMMS & $<5$ & $<5$ & $<5$ & 30.3 & 40.8 & 12.4 & 30.3 & 40.8 & 12.4 & $n / r$ & $\mathrm{n} / \mathrm{r}$ & $n / r$ \\
\hline $\begin{array}{l}200 \\
200\end{array}$ & D. & & 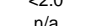 & 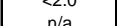 & 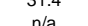 & 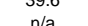 & 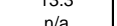 & $\begin{array}{l}31.4 \\
230\end{array}$ & 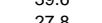 & 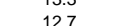 & 年 & 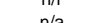 & $n / r$ \\
\hline & CLIA & & $n / a$ & $n / a$ & n/a & $n / a$ & $n / a$ & 31.0 & 43.2 & 14.9 & $n / a$ & $n / a$ & 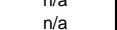 \\
\hline $204 b$ & LC-MSIMS & $n / d$ & $n / d$ & $n / d$ & 30.8 & 41.5 & 12.7 & 30.8 & 41.5 & 12.7 & $\mathrm{n} / \mathrm{d}$ & $<2.4$ & n/d \\
\hline $\begin{array}{l}209 \\
210 a\end{array}$ & $\begin{array}{l}\text { LC-MSIMS } \\
\text { RIA }\end{array}$ & $\begin{array}{l}<.0 \\
\text { n.a }\end{array}$ & $\begin{array}{l}<.0 \\
n / a\end{array}$ & $\begin{array}{l}<1.0 \\
\text { na }\end{array}$ & $\begin{array}{l}34.0 \\
\text { na }\end{array}$ & $\begin{array}{c}4.8 \\
\text { n/a }\end{array}$ & $\begin{array}{l}12.4 \\
n / a\end{array}$ & $\begin{array}{l}34.0 \\
32.1\end{array}$ & $\begin{array}{l}48.8 \\
40.2\end{array}$ & $\begin{array}{l}17.4 \\
17.4\end{array}$ & 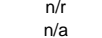 & n n/r $n$ & $\begin{array}{l}n / r \\
n / a\end{array}$ \\
\hline $210 \mathrm{~b}$ & CLIA & $\mathrm{n} / \mathrm{a}$ & $\mathrm{n} / \mathrm{a}$ & $n / a$ & n/a & $\mathrm{n} / \mathrm{a}$ & $\mathrm{n} / \mathrm{a}$ & 30.9 & 44.8 & $\mathrm{n} / \mathrm{r}$ & $n / a$ & $n / a$ & n/a \\
\hline $\begin{array}{l}{ }_{2}^{211} \\
2_{10}\end{array}$ & LC-MSMS & 0.0 & 0.0 & 0.0 & 37.8 & 49.1 & 12.6 & 37.8 & 49.1 & 12.6 & $n / r$ & $n / r$ & $\mathrm{n} / \mathrm{r}$ \\
\hline 213a & $\begin{array}{l}\text { LCMIMS } \\
\text { CUA }\end{array}$ & $<2$ & $<^{2}$ & $<2$ & 31.9 & 42.9 & 12.8 & 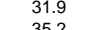 & 年2.9. & $\begin{array}{l}12.8 \\
12.8\end{array}$ & n/r & n/r & $n / r$ \\
\hline 213b & El & $\begin{array}{l}n / a \\
n / a\end{array}$ & $\begin{array}{l}n / a \\
n / a\end{array}$ & $\begin{array}{l}\text { nat } \\
\text { nala }\end{array}$ & 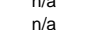 & 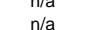 & 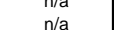 & 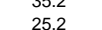 & $\begin{array}{l}48.4 \\
323\end{array}$ & 1.49 1.99 & 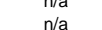 & 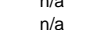 & 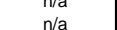 \\
\hline & & n/a & n/a & $n / a$ & n/a & $\mathrm{n} / \mathrm{a}$ & $n / a$ & 17.1 & 16.6 & 6.3 & $n / a$ & $n / a$ & $n / a$ \\
\hline 2140 & (C) & nala & n/a & n/a & n/a & n/a & n/a & 29.4 & 38.1 & 13.0 & n/a & n/a & n/a \\
\hline 215 & $\begin{array}{l}\text { LC-MSMS } \\
\text { LC }\end{array}$ & $<1.0$ & $<1.0$ & $<1.0$ & $\begin{array}{l}31.3 \\
34.8\end{array}-8$ & 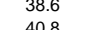 & $\begin{array}{l}12.2 \\
140 \\
140\end{array}$ & $\begin{array}{l}31.3 \\
348\end{array}$ & $\begin{array}{l}38.6 \\
480\end{array}$ & 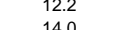 & nir & nor & $n / r$ \\
\hline 216 & LC-MSMS & 0.7 & 0.7 & 0.2 & 36.4 & 40.6 & 12.2 & 37.2 & 41.3 & 12.3 & 2.0 & 2.3 & 0.7 \\
\hline & & & & & 39.2 & 48.8 & 16.4 & 39.2 & 48.8 & 16.4 & $\mathrm{n} / \mathrm{r}$ & $\mathrm{n} / \mathrm{r}$ & n/r \\
\hline 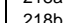 & SCASMS & 然 & na & n/a & n/a & n/a & n/a & 31.1 31. & 40.7 & 14.0 & n/a & n/a & n/a \\
\hline 220 & $\begin{array}{l}\text { LC-MSMS } \\
\text { LCMS }\end{array}$ & $n / d$ & $n=0.3$ & . & $\begin{array}{l}3.1 \\
310\end{array}$ & $\begin{array}{l}4.1 .8 \\
384\end{array}$ & $\begin{array}{l}17.7 \\
125\end{array}$ & 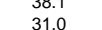 & $\begin{array}{l}42.1 \\
384\end{array}$ & $\begin{array}{l}4.7 .7 \\
1.25\end{array}$ & $\begin{array}{l}n=1 \\
n / r\end{array}$ & $\begin{array}{l}n=1 \\
n / r\end{array}$ & $n$ \\
\hline & LC-MSIMS & $<2.0$ & $<2.0$ & $<2.0$ & 30.1 & 35.3 & 14.9 & 30.1 & 35.3 & 14.9 & $n / r$ & $\mathrm{n} / \mathrm{r}$ & $n / r$ \\
\hline $221 \mathrm{~b}$ & LC-UV & 0.0 & 0.0 & 0.0 & 34.3 & 42.7 & 38.5 & 34.3 & 42.7 & 38.5 & $n / r$ & $n / r$ & $n / r$ \\
\hline $\begin{array}{l}2222 \\
2225\end{array}$ & CLA & n/a & n/a & nata & $\begin{array}{l}n / a \\
n=0\end{array}$ & nas & 策/a & $\begin{array}{l}35.3 \\
350\end{array}$ & $\begin{array}{l}40.1 \\
40.6\end{array}$ & $\begin{array}{l}15.0 \\
1.2\end{array}$ & n/a & n/a & n/a \\
\hline & & $\begin{array}{l}<5 \\
n / d\end{array}$ & s. $\begin{array}{c}5 \\
n / d\end{array}$ & $\begin{array}{l}<5.0 \\
n / d\end{array}$ & $\begin{array}{l}32.9 \\
37.0\end{array}$ & $\begin{array}{l}44.6 \\
45.7\end{array}$ & 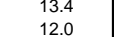 & $\begin{array}{l}32.9 \\
37.0\end{array}$ & $\begin{array}{l}44.6 \\
45.7\end{array}$ & $\begin{array}{l}\begin{array}{l}13.4 \\
12.0\end{array} \\
\text { the }\end{array}$ & $n / r$ & $\begin{array}{l}n / r \\
n / r\end{array}$ & \\
\hline 242 & LC-MSIMS & 0.5 & 0.4 & $\mathrm{n} / \mathrm{d}$ & 29.5 & 36.5 & 12.8 & 30.0 & 36.9 & 128 & 1.5 & 1.7 & 0.6 \\
\hline $243 a$ & LC.UV & 0.5 & 0.4 & $\mathrm{n} / \mathrm{d}$ & 29.5 & 36.6 & 12.7 & 29.8 & 37.0 & 12.9 & 1.5 & 1.7 & 0.7 \\
\hline & & $\begin{array}{l}0.5 \\
<5 \\
<5\end{array}$ & $\begin{array}{l}0.4 \\
<5\end{array}$ & 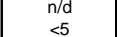 & $\begin{array}{l}29.3 \\
34.0\end{array}$ & $\begin{array}{l}36.4 \\
40.0\end{array}$ & $\begin{array}{l}12.7 \\
16.0\end{array}$ & $\begin{array}{l}30.0 \\
34.0\end{array}$ & $\begin{array}{l}37.0 \\
40.0\end{array}$ & & & $\begin{array}{l}1.8 \\
n / r\end{array}$ & $\begin{array}{l}0.6 \\
n / r\end{array}$ \\
\hline $\begin{array}{l}244 \\
249\end{array}$ & $\begin{array}{l}\text { LC-MS } \\
\text { LC-MSIS }\end{array}$ & $\begin{array}{r}<5 \\
<0.8\end{array}$ & $\begin{array}{l}<5 \\
<0.8\end{array}$ & $\begin{array}{c}<5 \\
<0.8\end{array}$ & 34.0 & 40.0 & $\begin{array}{l}16.0 \\
12.8\end{array}$ & $\begin{array}{l}\begin{array}{l}34.0 \\
30.4\end{array} \\
\text {. }\end{array}$ & $\begin{array}{l}40.0 \\
41.2\end{array}$ & $\begin{array}{l}16.0 \\
12.8\end{array}$ & $\begin{array}{l}n / r \\
1.5\end{array}$ & $\begin{array}{l}n=n / r \\
1.8\end{array}$ & $\begin{array}{l}n+1 \\
0.5 \\
0.5\end{array}$ \\
\hline 251 & LC-MSMS & $<4$ & $<4$ & n & 37.0 & 54.0 & 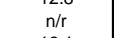 & 37.0 & 54.0 & . & . & $\mathrm{n} / \mathrm{r}$ & 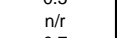 \\
\hline $\begin{array}{l}253 \\
255\end{array}$ & LCCMSMS & 0.7 & 0.6 & 0.1 & $\begin{array}{l}30.1 \\
307\end{array}$ & $\begin{array}{l}39.0 \\
39.0\end{array}$ & $\begin{array}{l}12.1 \\
1.27\end{array}$ & $\begin{array}{l}30.8 \\
3028\end{array}$ & $\begin{array}{l}39.6 \\
39.6\end{array}$ & $\begin{array}{l}12.2 \\
1.2\end{array}$ & 1.9 & 2.1 & 0.7 \\
\hline 256 & $\begin{array}{l}\mathrm{LC} \\
\mathrm{CL}\end{array}$ & $\begin{array}{l}0.7 \\
n / a\end{array}$ & $\mathrm{n} / \mathrm{a}$ & $\begin{array}{l}0.2 \\
\text { n/a }\end{array}$ & $\begin{array}{l}32.7 \\
n / a\end{array}$ & $\begin{array}{c}40.3 \\
\text { n/a }\end{array}$ & $\begin{array}{l}\begin{array}{l}12.7 \\
\text { n/a }\end{array} \\
\text { a }\end{array}$ & $\begin{array}{l}\begin{array}{l}33.4 \\
33.0\end{array} \\
\text { a }\end{array}$ & $\begin{array}{l}41.0 \\
35.8\end{array}$ & $\begin{array}{l}12.9 \\
11.4\end{array}$ & $\begin{array}{l}n / r \\
n / a\end{array}$ & $\begin{array}{l}n=1 \\
n / a\end{array}$ & $\begin{array}{l}n / r \\
n / a\end{array}$ \\
\hline & CLIA & $n / a$ & $n / a$ & $n / a$ & $n / a$ & $n / a$ & $n / a$ & - & 42.0 & & & n/a & \\
\hline 258 & CLIA & $n / a$ & $n / a$ & $n / a$ & n/a & n/a & n/a & 33.9 & 64.4 & 13.6 & $n / a$ & $\mathrm{n} / \mathrm{a}$ & n/a \\
\hline & LC-MSMS & & & & & 45.2 & 10.3 & & 45.2 & & & $\mathrm{n} / \mathrm{r}$ & $\mathrm{n} / \mathrm{r}$ \\
\hline . & & & nia & . & . & nia & . & & & & $n / a$ & a & nat \\
\hline 263 & CLIA & n/a & $\mathrm{n} / \mathrm{a}$ & $\mathrm{n} / \mathrm{a}$ & $\mathrm{n} / \mathrm{a}$ & $\mathrm{n} / \mathrm{a}$ & $\mathrm{n} / \mathrm{a}$ & 33.7 & 37.6 & 12.8 & $\mathrm{n} / \mathrm{a}$ & nla & $\begin{array}{l}n / a \\
n / a\end{array}$ \\
\hline 264 & LC-MSIMS & 0.6 & 0.6 & 0.1 & 41.0 & 39.2 & 13.9 & 41.6 & 39.8 & 14.0 & $n / r$ & $n / r$ & $\mathrm{n} / \mathrm{r}$ \\
\hline 268 & LC-M & 0.0 & 0.0 & 0.0 & 50 & 44.0 & 13.0 & $\begin{array}{l}35.0 \\
35.0\end{array}$ & .0. & 13.0 & $\mathrm{n} / \mathrm{r}$ & $n / r$ & n/r \\
\hline $\begin{array}{l}2006 \\
2666\end{array}$ & LC- & na & & na & & & & & & & & & $n / r$ \\
\hline 267 & CLEIA & $n / a$ & $n / a$ & n/a & n/a & $n / a$ & $n / a$ & 30.4 & $\begin{array}{l}39.3 \\
\end{array}$ & 12.4 & $n / a$ & $n / a$ & n/a \\
\hline 年 & & & & & & & & & & & & & \\
\hline & NIST Ve & 0.68 & 0.65 & $0.1^{*}$ & 31.3 & 39.4 & 12.4 & 32.0 & 40.1 & 12.5 & 1.7 & 2.1 & 0.65 \\
\hline & & 0.06 & & & & & & & & 0.4 & 0.1 & 0.1 & 0.03 \\
\hline
\end{tabular}

